\title{
Effect of level of nutrition on splanchnic blood flow and oxygen consumption in sheep*
}

\author{
BY D. G. BURRIN ${ }^{1} \uparrow$, C. L. FERRELL ${ }^{2}$, J. H. EISEMANN ${ }^{2}$, R. A. BRITTON ${ }^{1+}$ \\ AND J. A. NIENABER ${ }^{2}$ \\ ${ }^{1}$ Department of Animal Sciences, University of Nebraska, Lincoln, Nebraska 68583-0908, USA and \\ ${ }^{2}$ Roman L. Hruska Meat Animal Research Center, Agricultural Research Service, USDA, \\ Clay Center, Nebraska, USA
}

(Received 10 January 1989 - Accepted 3 February 1989)

\begin{abstract}
The objective of the present study was to measure changes in splanchnic blood flow and oxygen consumption in sheep fed on a high-concentrate diet ad lib. (ADLIB) or an amount sufficient to maintain body-weight (MAINT) for $21 \mathrm{~d}$. Eleven ram lambs were surgically implanted with chronic indwelling catheters in the portal, hepatic and mesenteric veins and mesenteric artery to measure blood flow and net $\mathrm{O}_{2}$ flux through the liver and portal-drained viscera (PDV). During the $21 \mathrm{~d}$ period, PDV $(P<0.05)$ and liver $(P<0.01)$ blood flow increased in ADLIB and decreased in MAINT lambs (treatment $\times$ day, linear). After $21 \mathrm{~d}, \mathrm{O}_{2}$ consumptions in PDV and liver of MAINT lambs were 37 and $63 \%$ lower than in ADLIB lambs. In the control period, total splanchnic tissues represented an average of $52 \%$ of whole body $\mathrm{O}_{2}$ consumption. After $21 \mathrm{~d}$, the relative contributions of PDV and liver to whole-body $\mathrm{O}_{2}$ consumption were 28 and $41 \%$ in ADLIB and 19 and $22 \%$ in MAINT lambs respectively. Allometric regression variables indicate that liver $\mathrm{O}_{2}$ consumption responds more rapidly to changes in metabolizable energy intake than portal $\mathrm{O}_{2}$ consumption. These results indicate that blood flow and $\mathrm{O}_{2}$ consumption in both PDV and liver are related to level of nutrition. Furthermore, splanchnic tissues represent a significant component of whole-body $\mathrm{O}_{2}$ consumption that is subject to manipulation by level of nutrition.
\end{abstract}

Oxygen consumption: Splanchnic blood flow: Sheep.

The classical work of Brody (1945) and Kleiber (1947) demonstrated that much of the variation in metabolic rate between adult mammalian species can be attributed to differences in body-weight. It has become readily apparent, however, that within a species metabolic rate per unit body-weight can be influenced by factors such as age (Graham et al. 1974), breed (Smith \& Baldwin, 1974; Jenkins \& Ferrell, 1983; Ferrell \& Jenkins, 1984) and level of nutrition (Marston, 1948; Ledger \& Sayers, 1977). Variations in metabolic rate and protein metabolism have been attributed to the allometric relation between visceral organ size and body-weight during pre- and post-natal development (Holliday et al. 1967; Munro, 1969; Bell et al. 1987).

Relative to their contribution to body-weight, the visceral organs maintain a disproportionately large share of whole-body metabolism during pre- and post-natal growth. In development of the ovine fetus, the liver, kidneys, heart and brain account for $6.5 \%$ of body-weight and $40 \%$ of total fetal oxygen consumption (Bell et al. 1987). In the ovine fetus, the fractional protein synthesis rates of liver, kidneys, brain, heart and gastrointestinal tissue are $78,45,37,14$, and $71 \% / \mathrm{d}$ respectively and represent nearly $45 \%$ of whole-body protein synthesis (Schaefer \& Krishnamurti, 1984). Visceral organ

* Published as paper no. 8565, Journal Series, Nebraska Agriculture Experiment Station.

$\dagger$ Present address: USDA/ARS Children's Nutrition Research Center, Department of Pediatrics, Baylor College of Medicine, Houston, Texas, USA.

$\ddagger$ For reprints. 
metabolism during post-natal development is also characterized by a high rate of $\mathrm{O}_{2}$ consumption relative to the whole body (Edelstone \& Holzman, 1981; Webster, 1981; Huntington \& Tyrrell, 1985; Reynolds et al. 1986).

The effect of level of nutrition on basal metabolic rate or maintenance energy requirements has been found to be highly correlated with changes in relative weights of visceral organs (Koong et al. 1982; Ferrell et al. 1986). Visceral organ metabolic activity is a function of both organ size and tissue metabolic activity. The effect of level of nutrition on visceral organ metabolism is reflected in the relation between metabolizable energy intake (MEI), blood flow and $\mathrm{O}_{2}$ consumption of liver and portal-drained viscera (PDV) (Webster et al. 1975; Huntington \& Prior, 1983; Lomax \& Baird, 1983; Huntington, 1984; Weighart et al. 1986; Reynolds \& Tyrrell, 1987). Changes in metabolic activity of organ or splanchnic tissues may be partly responsible for changes observed in whole-body metabolic rate. In the present study, our objective was to measure the effect of level of nutrition on splanchnic blood flow and $\mathrm{O}_{2}$ consumption, and determine the relative contribution of these tissues to whole-body $\mathrm{O}_{2}$ consumption (WBO).

\section{MATERIALS AND METHODS \\ Animals, diet and feeding regimen}

Eleven crossbred ram lambs with an average initial weight of $35 \mathrm{~kg}$ were used in the experiment. The lambs were housed in individual pens approximately $1.75 \mathrm{~m}^{2}$, with controlled lighting (lights on 08.00-20.00 hours). Lambs were fed on a pelleted highconcentrate diet (Table 1$)$ in four equal portions daily at $6 \mathrm{~h}$ intervals $(02.00,08.00,14.00$, 20.00 hours) with free access to water.

At $14 \mathrm{~d}$ before initiating the experiment, lambs were fed on the high-concentrate diet at a level of $30 \mathrm{~g}$ dry matter (DM) $/ \mathrm{kg}$ body-weight. Lambs were randomly assigned to either an ad lib. (ADLIB) or a maintenance (MAINT) treatment. The experimental period consisted of a control period (day 0 ) and three subsequent periods at $7 \mathrm{~d}$ intervals. During the $21 \mathrm{~d}$ experimental period, MAINT lambs were fed to maintain body-weight by restricting feed intake. Lambs were weighed twice weekly and feed allowances were adjusted to maintain body-weight. Daily feed intake of lambs in group ADLIB was rernried

\section{Surgical procedures}

In the $14 \mathrm{~d}$ period before beginning the experiment, lambs were surgically fitted with chronic indwelling catheters in the portal, hepatic and mesenteric veins and mesenteric artery. Portal catheters equipped with a tapered bone chip at the tip (Tefion, i.d. $1.3 \mathrm{~mm}$, o.d. $2.13 \mathrm{~mm}$, length $800 \mathrm{~mm}$; Cope Plastics, Topeka, KS) were inserted into the hepatic portal vessel so that the tip was approximately $100-150 \mathrm{~mm}$ caudal to the base of the liver. Hepatic vein catheters (Tygon, i.d. $1.27 \mathrm{~mm}$, o.d. $2.29 \mathrm{~mm}$ ) were inserted through the dorsal or ventral surface of the left lateral hepatic lobe into a branch of the hepatic vein. Insertion of the hepatic vein catheter was facilitated by the use of a Teflon-coated wire guide $(0.89$ $\mathrm{mm} \times 1450 \mathrm{~mm}$; USCI-Bard, Billerica, MA) which was inserted into the vessel via a 16gauge needle. After placement of the portal and hepatic vein catheters, blood samples were drawn from these vessels and analysed for percentage $\mathrm{O}_{2}$ saturation (Hemoximeter; Radiometer America Inc., Westlake, $\mathrm{OH}$ ) during the surgical procedure in an attempt to verify proper placement of the catheters. Typically, the percentage $\mathrm{O}_{2}$ saturation of hepatic blood was 10-15 units lower than portal venous blood. Mesenteric vein and arterial catheters (Tygon, i.d. $1.02 \mathrm{~mm}$, o.d. $1.78 \mathrm{~mm}$ ) were inserted into branches of the anterior mesenteric vein and artery. All catheters were filled with sterile saline (1000 units 
Table 1 Diet composition ( $\mathrm{g} / \mathrm{kg}$ diet on a dry matter basis)

\begin{tabular}{lc}
\hline Ingredient & \\
\hline Ground maize & 657.0 \\
Lucerne (Medicago sativa) hay & 196.0 \\
Soya-bean meal & 80.8 \\
Liquid molasses & $19 \cdot 6$ \\
Lignin sulphate & 19.6 \\
Lasalocid premix & 14.6 \\
Limestone & 6.9 \\
Ammonium chloride & $5 \cdot 0$ \\
Vitamin A,D,E premix & 0.5 \\
Metabolizable energy* & 11.94 \\
Crude protein (nitrogen $\times 6.25)$ & 145 \\
\hline
\end{tabular}

* MJ/kg (calculated from National Research Council, 1984).

heparin $/ \mathrm{ml}, 9 \mathrm{~g}$ sodium chloride $/ 1,10 \mathrm{~g}$ benzyl alcohol $/ 1,0.5 \mathrm{~g}$ penicillin-streptomycin $/ 1$ ) exteriorized through the body wall and skin, and wrapped in a gauze pouch. Lambs were treated with $5 \mathrm{ml}$ antibiotic daily for $3 \mathrm{~d}$ after surgery and allowed at least 7-10 d before beginning sampling protocols on day 0 . In the recovery period, daily DM intake was limited to $30 \mathrm{~g} / \mathrm{kg}$ body-weight.

\section{Sampling protocol}

Lambs were weighed and transferred to metabolism crates before initiating sampling. Animals were routinely placed in the metabolism crates during the $14 \mathrm{~d}$ preliminary period to acclimate them to the sampling environment. At $15 \mathrm{~min}$ before the first sample, each animal received a $15 \mathrm{ml}$ priming dose of $3 \mathrm{~g} p$-amino hippuric acid (PAH)/100 $\mathrm{ml}$ into the mesenteric vein. Immediately thereafter, PAH $(3 \mathrm{~g} / 100 \mathrm{ml})$ was infused continuously at a flow-rate of approximately $0.8 \mathrm{ml} / \mathrm{min}$ into the mesenteric vein for a $6 \mathrm{~h}$ period (14.00-20.00 hours, days 0 and $21 ; 08.00-14.00$ hours, days 7 and 14) using a calibrated syringe pump (Harvard Bioscience, South Natick, MA). Blood samples ( 3 and $1 \mathrm{ml}$ ) were withdrawn from the portal and hepatic veins and mesenteric arterial catheters at 30 min intervals over the $6 \mathrm{~h}$ infusion period. During the sampling period, lambs were allowed free access to water and their $6 \mathrm{~h}$ allotment of feed.

Whole-blood samples were placed on ice and transported to the laboratory. A portion of whole blood was added to ice-cold heparinized $(25$ units $/ \mathrm{ml})$, deionized water $(1: 1, \mathrm{v} / \mathrm{v})$ and the diluted blood sample was analysed for $\mathrm{PAH}$ according to the procedures described by Katz \& Bergman (1969). The $1 \mathrm{ml}$ blood sample was analysed immediately for blood haemoglobin, $\mathrm{O}_{2}$ saturation (Hemoximeter) and packed cell volume. The Hemoximeter was calibrated both for haemoglobin and $\mathrm{O}_{2}$ saturation. Haemoglobin was measured on several samples of sheep blood using Drabkin's reagent and haemoglobin standard (Sigma Chemical Co., St Louis, MO). Using additional portions of the same blood samples, the Hemoximeter was adjusted until the haemoglobin readings were the same as those determined with Drabkin's reagent. A fully reduced blood sample was prepared by aspirating blood into a capillary tube containing sodium dithionite and tris(hydroxymethyl)animomethane (Radiometer, Copenhagen, Denmark). This sample was used to calibrate blood $\mathrm{O}_{2}$ saturation at $0 \%$. A fully oxidized blood sample was prepared by exposing a small quantity of blood to air. This sample was used to calibrate blood $\mathrm{O}_{2}$ saturation at $100 \%$. 


\section{Calculations}

Whole-blood $\mathrm{O}_{2}$ concentration was calculated using the following equation:

$$
\mathrm{O}_{2}(\mathrm{mmol} / \mathrm{l})=(X)(Y)(1 \cdot 34)(1 / 22 \cdot 4)(10),
$$

where $X$ is blood haemoglobin $(\mathrm{g} / 100 \mathrm{ml}), Y$ is percentage $\mathrm{O}_{2}$ saturation, 1.34 is $\mathrm{ml} \mathrm{O}_{2} / \mathrm{g}$ haemoglobin, and 22.4 is $\mathrm{ml} \mathrm{O}_{2} / \mathrm{mmol} \mathrm{O}_{2}$. Whole-blood flow and $\mathrm{O}_{2}$ consumption rates were calculated using the equations reported by Katz \& Bergman (1969), which are based on the Fick principle of arterio-venous concentration difference and flow rate. Wholeblood flow rate was estimated, based on dilution of $\mathrm{PAH}$, using the following equations:

$$
\begin{aligned}
& F_{\mathrm{pv}}=I /\left(C_{\mathrm{pv}}-C_{\mathrm{a}}\right), \\
& F_{\mathrm{hv}}=I /\left(C_{\mathrm{hv}}-C_{\mathrm{a}}\right),
\end{aligned}
$$

where $F_{\mathrm{pv}}$ and $F_{\mathrm{hv}}$ are portal and hepatic vein flow rates $(1 / \mathrm{h}), C_{\mathrm{pv}}, C_{\mathrm{hv}}$ and $C_{\mathrm{a}}$ are the wholeblood concentrations of PAH (mg/l) in the portal vein, hepatic vein and mesenteric artery respectively, and $I$ is the infusion rate of PAH $(\mathrm{mg} / \mathrm{h})$. Hepatic arterial flow was calculated as hepatic-vein minus portal-vein flow rate. Splanchnic $\mathrm{O}_{2}$ fluxes were calculated using the following equations:

$$
\begin{aligned}
\text { portal } \mathrm{O}_{2} \text { flux }(\mathrm{mmol} / \mathrm{h}) & =F_{\mathrm{pv}}\left(C_{\mathrm{a}}-C_{\mathrm{pv}}\right), \\
\text { hepatic } \mathrm{O}_{2} \text { flux }(\mathrm{mmol} / \mathrm{h}) & =F_{\mathrm{pv}}\left(C_{\mathrm{pv}}-C_{\mathrm{hv}}\right)+F_{\mathrm{ha}}\left(C_{\mathrm{a}}-C_{\mathrm{hv}}\right),
\end{aligned}
$$

where $F_{\mathrm{ha}}$ is hepatic arterial flow rate $(1 / \mathrm{h})$ and $C_{\mathrm{a}}, C_{\mathrm{pv}}$ and $C_{\mathrm{hv}}$ are the whole-blood $\mathrm{O}_{2}$ concentrations $(\mathrm{mmol} / \mathrm{l})$ in the mesenteric artery and portal and hepatic veins respectively.

\section{Indirect calorimetry protocol}

In the control (day 0 ) and final (day 21) periods, lambs were transferred to individual calorimetry chambers and allowed $1 \mathrm{~h}$ to adapt. Calorimetry measurements continued for a $6 \mathrm{~h}$ period (08.00-14.00 hours), during which all lambs were allowed free access to water and their respective $6 \mathrm{~h}$ allotment of feed (Nienaber \& Maddy, 1985). Total animal $\mathrm{O}_{2}$ consumption was calculated based on estimates of total air flow and $\mathrm{O}_{2}$ contents of input and output air. Following calorimetry measurements, lambs were weighed and transferred to metabolism crates for blood sampling procedures.

\section{Statistical procedures}

Data were analysed according to the general linear models procedure of the Statistical Analysis System (SAS, 1982). The design was completely random with a split-plot in time (Steel \& Torrie, 1980). Sources of whole-plot variation were animal and treatment, with animal within treatment as the error term. Subplot sources of variation were day and the treatment $\times$ day interaction, with days $\times$ animals within treatment as the subplot error term. In addition, the effect of day and treatment $x$ day interactions were partitioned into linear, quadratic and cubic responses. Values are presented as least-squares means and pooled standard errors of the least squares means.

\section{RESULTS}

At the outset of the experiment, a complete complement of samples was not obtained for all animals because of problems of catheter placement and patency (Table 2). In two animals (one from each treatment) catheters which were believed to be in the hepatic vein were actually located in branches of the hepatic portal vein and were not sampled. In addition, one animal in group ADLIB lost patency of the portal catheter. Another animal 
Table 2. No. of animals sampled during the experimental period

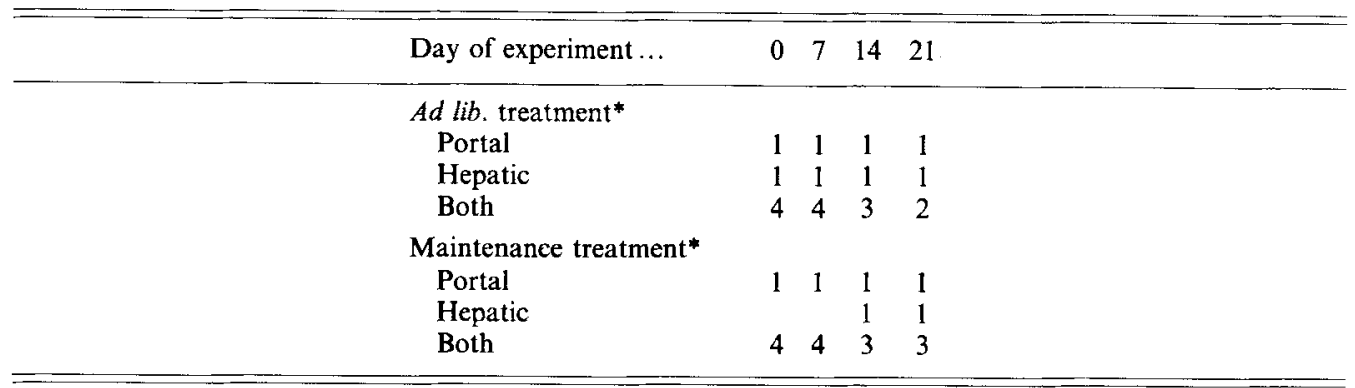

* For details, see p. 24.

Table 3. Whole-blood haemoglobin and packed cell volume of sheep fed ad lib. or at maintenance levels*

(No. of animals in each sampling period is shown in parentheses)

\begin{tabular}{|c|c|c|c|c|c|}
\hline Day of experiment... & 0 & 7 & 14 & 21 & $\begin{array}{c}\text { Pooled } \\
\text { SE }\end{array}$ \\
\hline \multicolumn{6}{|l|}{ Haemoglobin $(\mathrm{g} / \mathrm{l})$} \\
\hline Ad lib. & $102(6)$ & $111(6)$ & $113(5)$ & $103(4)$ & $10 \cdot 0$ \\
\hline Maintenance & $109(5)$ & $110(5)$ & $105(5)$ & $107(5)$ & \\
\hline \multicolumn{6}{|l|}{ Packed cell volume } \\
\hline Ad lib. & $0 \cdot 263$ & $0 \cdot 283$ & $0 \cdot 286$ & $0 \cdot 265$ & 0.0255 \\
\hline Maintenance & 0.275 & 0.275 & 0.259 & 0.267 & \\
\hline
\end{tabular}

* For details, see p. 24 and Table 2.

in group ADLIB was removed from the study after 2 weeks as a result of an apparent acidosis problem. Correct catheter placement was verified on necropsy of all animals that were sampled during the experiment. Throughout the experiment, the intensive blood sampling protocol posed a potential challenge for animals to maintain blood volume and erythrocyte levels. However, blood haemoglobin and packed cell volume levels were not affected during the $21 \mathrm{~d}$ experiment (Table 3 ).

A treatment $x$ day interaction was observed for body-weight (linear, $P<0.01$ ) and feed intake (linear, $P<0.01$; quadratic, $P<0.02$ ) indicating our experimental protocol was adequate. During the $21 \mathrm{~d}$ period, lambs in the MAINT group maintained a relatively constant body-weight and feed intake (Table 4). The ADLIB lambs consumed nearly twice the amount of feed required to maintain body-weight in MAINT lambs. Calculated daily MEI expressed per unit metabolic body size $\left(\mathrm{kJ} / \mathrm{kg}\right.$ body-weight $\left.{ }^{0.75}\right)$ ranged from 347 to 423 and from 732 to 812 for MAINT and ADLIB lambs respectively. ADLIB lambs gained an average of $238 \mathrm{~g} / \mathrm{d}$, although no change in average body-weight occurred in the final $7 \mathrm{~d}$ period. Maintenance of animals at constant body-weight has been shown to result in a steady decline in maintenance feed requirements (Ledger \& Sayers, 1977); however, a consistent decrease in intake was not observed for the MAINT lambs.

Components of splanchnic blood flow exhibited treatment $x$ day interactions (Table 5). Portal blood flow varied with period (treatment $\times$ day, cubic, $P<0.07$ ) and was generally associated with energy level. Flows in the hepatic vein and artery were affected by energy level and time (treatment $\times$ day, linear, $P<0.09$ and $P<0.01$ respectively). Rates of blood 
Table 4. Body-weights and feed intakes of sheep fed ad lib. or at maintenance levels* (No. of animals in each sampling period is shown in parentheses)

\begin{tabular}{|c|c|c|c|c|c|}
\hline Day of experiment ... & 0 & 7 & 14 & 21 & $\begin{array}{c}\text { Pooled } \\
\text { SE }\end{array}$ \\
\hline $\begin{array}{l}\text { Body-wt }(\mathrm{kg}) \dagger \\
\text { Ad lib. } \\
\text { Maintenance }\end{array}$ & $\begin{array}{l}36(6) \\
34(5)\end{array}$ & $\begin{array}{l}39(6) \\
34(5)\end{array}$ & $\begin{array}{l}41(5) \\
33(5)\end{array}$ & $\begin{array}{l}41(4) \\
33(5)\end{array}$ & $1 \cdot 0$ \\
\hline $\begin{array}{l}\text { Feed intake ( } \mathrm{g} \text { dry matter } / \mathrm{d}) \dagger \ddagger \\
\text { Ad lib. } \\
\text { Maintenance }\end{array}$ & $\begin{array}{l}894 \\
774\end{array}$ & $\begin{array}{r}1066 \\
496\end{array}$ & $\begin{array}{r}1004 \\
396\end{array}$ & $\begin{array}{r}1110 \\
451\end{array}$ & $124 \cdot 3$ \\
\hline
\end{tabular}

* For details, see p. 24 and Table 2.

$\dagger$ Treatment $\times$ day, linear $(P<0.01)$.

$\ddagger$ Treatment $\times$ day, quadratic $(P<0.02)$.

Table 5. Components of splanchnic blood flow $(l / h)$ of sheep fed ad lib. or at maintenance levels*

(No. of animals in each sampling period is shown in parentheses)

\begin{tabular}{|c|c|c|c|c|c|}
\hline Day of experiment... & 0 & 7 & 14 & 21 & $\begin{array}{l}\text { Pooled } \\
\text { SE }\end{array}$ \\
\hline $\begin{array}{l}\text { Portal vein } \dagger \ddagger \\
\text { Ad lib. } \\
\text { Maintenance }\end{array}$ & $\begin{array}{r}108(5) \\
93(5)\end{array}$ & $\begin{array}{r}108(5) \\
90(5)\end{array}$ & $\begin{array}{r}135(4) \\
81(5)\end{array}$ & $\begin{array}{r}114(3) \\
86(4)\end{array}$ & 15.5 \\
\hline $\begin{array}{l}\text { Hepatic vein§ } \\
\quad \text { Ad lib. } \\
\text { Maintenance }\end{array}$ & $\begin{array}{l}135(5) \\
119(5)\end{array}$ & $\begin{array}{l}138(5) \\
112(5)\end{array}$ & $\begin{array}{l}171(4) \\
101(4)\end{array}$ & $\begin{array}{l}170(3) \\
100(4)\end{array}$ & $17 \cdot 1$ \\
\hline $\begin{array}{l}\text { Hepatic artery } \$ \\
\quad \text { Ad lib. } \\
\text { Maintenance }\end{array}$ & $\begin{array}{l}35(4) \\
28(4)\end{array}$ & $\begin{array}{l}34(4) \\
22(4)\end{array}$ & $\begin{array}{l}62(3) \\
20(3)\end{array}$ & $\begin{array}{l}63(2) \\
19(3)\end{array}$ & 16.5 \\
\hline
\end{tabular}

\footnotetext{
* For details, see p. 24 and Table 2.

+ Treatment $x$ day, cubic $(P<0.07)$.

+ Treatment $\times$ day, linear $(P<0.09)$.

$\S$ Treatment $\times$ day, linear $(P<0.01)$.
}

flow are in general agreement with previous reports (Bensadoun et al. 1962; Katz \& Bergman, 1969; Huntington et al. 1980). All components of splanchnic blood flow were higher in ADLIB than MAINT lambs throughout the $21 \mathrm{~d}$ period. After $21 \mathrm{~d}$, portal and hepatic vein blood flows in MAINT lambs were $25-41 \%$ lower than that of ADLIB lambs. Estimates of hepatic arterial flow exhibited similar actual variation to the other blood flow estimates. In venous blood flow measurements using indicator dilution, a potential source of error is unrepresentative sampling due to laminar flow and improper mixing of indicator (Katz \& Bergman, 1969; Ushioda et al. 1982; Eisemann et al. 1987). In this regard, the turbulence of flow through the hepatic portal venous system would probably provide for more complete mixing of PAH in the hepatic vein, while the potential for streaming and inadequate mixing would be greater in the portal vein.

Arterial $\mathrm{O}_{2}$ and hepatic arterio-venous (A-V) difference in $\mathrm{O}_{2}$ were not affected by treatment (Table 6). Portal A-V difference decreased in the MAINT lambs, but not in the ADLIB group (treatment $\times$ day, linear, $P<0 \cdot 10$ ). All components of splanchnic $\mathrm{O}_{2}$ 
Table 6. Whole-blood arterial oxygen and aterio-venous $(A-V)$ concentration differences of sheep fed ad lib. or at maintenance levels*

(No. of animals in each sampling period is shown in parentheses)

\begin{tabular}{|c|c|c|c|c|c|}
\hline Day of experiment ... & 0 & 7 & 14 & 21 & $\begin{array}{c}\text { Pooled } \\
\text { SE }\end{array}$ \\
\hline $\begin{array}{l}\text { Arterial (mM) } \\
\quad \text { Ad lib. } \\
\text { Maintenance }\end{array}$ & $\begin{array}{l}6 \cdot 0(6) \\
6 \cdot 3(5)\end{array}$ & $\begin{array}{l}6 \cdot 3(6) \\
6 \cdot 2(5)\end{array}$ & $\begin{array}{l}6.4(5) \\
6.0(5)\end{array}$ & $\begin{array}{l}6 \cdot 1(4) \\
6 \cdot 1(5)\end{array}$ & $0 \cdot 76$ \\
\hline $\begin{array}{l}\text { Portal A-V (mM) } \dagger \\
\text { Ad lib. } \\
\text { Maintenance }\end{array}$ & $\begin{array}{l}1.7(5) \\
1.8(5)\end{array}$ & $\begin{array}{l}1.5(5) \\
1.6(5)\end{array}$ & $\begin{array}{l}1.4(4) \\
1.5(4)\end{array}$ & $\begin{array}{l}1 \cdot 6(3) \\
1 \cdot 3(4)\end{array}$ & $0 \cdot 18$ \\
\hline $\begin{array}{l}\text { Hepatic A.V (mM) } \\
\text { Ad lib. } \\
\text { Maintenance }\end{array}$ & $\begin{array}{l}3 \cdot 1(5) \\
2 \cdot 8(5)\end{array}$ & $\begin{array}{l}2.7(5) \\
2.5(5)\end{array}$ & $\begin{array}{l}2 \cdot 3(4) \\
2 \cdot 5(4)\end{array}$ & $\begin{array}{l}2 \cdot 5(3) \\
2 \cdot 3(4)\end{array}$ & $0 \cdot 24$ \\
\hline
\end{tabular}

* For details, see p. 24 and Table 2.

+ Treatment $x$ day, linear $(P<0 \cdot 10)$.

Table 7. Components of splanchnic oxygen consumption of sheep fed ad lib. or at maintenance levels* $(\mathrm{mmol} / \mathrm{h})$

(No. of animals in each sampling period is shown in parentheses)

\begin{tabular}{|c|c|c|c|c|c|}
\hline Day of experiment ... & 0 & 7 & 14 & 21 & $\begin{array}{c}\text { Pooled } \\
\text { SE }\end{array}$ \\
\hline $\begin{array}{l}\text { Portal-drained viscera } \dagger \\
\text { Ad lib. } \\
\text { Maintenance }\end{array}$ & $\begin{array}{l}181(5) \\
164(5)\end{array}$ & $\begin{array}{l}164(5) \\
143(5)\end{array}$ & $\begin{array}{l}187(4) \\
118(4)\end{array}$ & $\begin{array}{l}182(3) \\
114(4)\end{array}$ & $23 \cdot 0$ \\
\hline $\begin{array}{l}\text { Liver } \\
\quad \text { Ad lib. } \\
\text { Maintenance }\end{array}$ & $\begin{array}{l}224(4) \\
165(4)\end{array}$ & $\begin{array}{l}227(4) \\
135(4)\end{array}$ & $\begin{array}{l}286(3) \\
118(3)\end{array}$ & $\begin{array}{l}315(2) \\
117(3)\end{array}$ & $54 \cdot 3$ \\
\hline $\begin{array}{l}\text { Total splanchnic } \dagger \\
\text { Ad lib. } \\
\text { Maintenance }\end{array}$ & $\begin{array}{l}441(5) \\
325(5)\end{array}$ & $\begin{array}{l}372(5) \\
279(5)\end{array}$ & $\begin{array}{l}409(4) \\
249(4)\end{array}$ & $\begin{array}{l}445(3) \\
226(4)\end{array}$ & $57 \cdot 6$ \\
\hline
\end{tabular}

* For details, see p. 24 and Table 2.

$\dagger$ Treatment $\times$ day, linear $(P<0.01)$.

consumption were higher in ADLIB than MAINT lambs and had significant $(P<0.01)$ treatment $x$ day interactions (Table 7). After $21 \mathrm{~d}$ of feed restriction, $\mathrm{O}_{2}$ consumption by PDV, liver and total splanchnic tissues in MAINT lambs decreased by approximately $30 \%$ compared with measurements in the control period. In addition, $\mathrm{O}_{2}$ consumption by PDV, liver and total splanchnic tissues in MAINT lambs was 37-63\% lower than that of ADLIB lambs. The effects of level of nutrition on liver $\mathrm{O}_{2}$ consumption were similar to trends observed in liver $\mathrm{O}_{2}$ consumption predicted from measurements in vitro (Ferrell \& Koong, 1985; Burrin et al. 1987). Extraction of $\mathrm{O}_{2}$ by PDV tissues was not affected by treatment (Table 8); however, liver $\mathrm{O}_{2}$ extraction was higher in ADLIB than in MAINT lambs.

WBO in ADLIB lambs was similar in the control and final periods (Table 9); however, in MAINT lambs WBO decreased by $10 \%$ during the $21 \mathrm{~d}$ period. In the control period, the PDV and liver accounted for averages of 24 and $28 \%$ of WBO respectively across 
Table 8. Splanchnic tissue oxygen extraction ratios of sheep fed ad lib. or at maintenance levels*

(No. of animals in each sampling period is shown in parentheses)

\begin{tabular}{|c|c|c|c|c|c|}
\hline Day of experiment... & 0 & 7 & 14 & 21 & $\begin{array}{c}\text { Pooled } \\
\text { SE }\end{array}$ \\
\hline $\begin{array}{l}\text { Portal-drained viscera } \\
\text { Ad lib. } \\
\text { Maintenance }\end{array}$ & $\begin{array}{l}0.28(5) \\
0.26(5)\end{array}$ & $\begin{array}{l}0.24(5) \\
0.27(5)\end{array}$ & $\begin{array}{l}0.28 \text { (4) } \\
0.24 \text { (4) }\end{array}$ & $\begin{array}{l}0.26(3) \\
0.25(4)\end{array}$ & 0.033 \\
\hline $\begin{array}{l}\text { Liver } \dagger \\
\quad \text { Ad lib. } \\
\text { Maintenance }\end{array}$ & $\begin{array}{l}0.40(4) \\
0.31(4)\end{array}$ & $\begin{array}{l}0.39(4) \\
0.33(4)\end{array}$ & $\begin{array}{l}0.36(3) \\
0.31(3)\end{array}$ & $\begin{array}{l}0.37 \text { (2) } \\
0.28 \text { (3) }\end{array}$ & 0.047 \\
\hline
\end{tabular}

* For details see p, 24 and Table 2.

$\dagger$ Treatment $(P<0.05)$.

Table 9. Components of whole body oxygen consumption of sheep fed ad lib. or at maintenance levels*

(No. of observations is shown in parentheses)

\begin{tabular}{|c|c|c|c|}
\hline $\mathrm{O}_{2}$ consumption & Control & Final & $\begin{array}{c}\text { Pooled } \\
\text { SE }\end{array}$ \\
\hline $\begin{array}{l}\text { Whole body }(\mathrm{WB})(1 / \mathrm{h}) \\
\text { Ad lib. } \\
\text { Maintenance }\end{array}$ & $\begin{array}{l}16 \cdot 3(6) \\
15 \cdot 2(5)\end{array}$ & $\begin{array}{l}16 \cdot 2(3) \\
13 \cdot 7(4)\end{array}$ & 1.66 \\
\hline $\begin{array}{l}\text { Portal-drained viscera }(\% \mathrm{WB}) \dagger \\
\quad \text { Ad lib. } \\
\text { Maintenance }\end{array}$ & $\begin{array}{l}24(5) \\
24(5)\end{array}$ & $\begin{array}{l}28(3) \\
19(4)\end{array}$ & $5 \cdot 2$ \\
\hline $\begin{array}{l}\text { Liver }(\% \mathrm{WB}) \ddagger \\
\quad \text { Ad lib. } \\
\text { Maintenance }\end{array}$ & $\begin{array}{l}31(4) \\
25(4)\end{array}$ & $\begin{array}{l}41(2) \\
22(3)\end{array}$ & $2 \cdot 6$ \\
\hline
\end{tabular}

\footnotetext{
* For details, see p. 24 and Table 2.

$\dagger$ Treatment $(P<0.05)$.

$\ddagger$ Treatment $\times$ period $(P<0.01)$.
}

treatments. Thus, total splanchnic tissues represented $52 \%$ of $\mathrm{WBO}$, which is consistent with estimates reported by Webster (1981). In addition, these estimates of the relative contribution of liver and PDV to WBO are similar to previous reports in Holstein cows and steers (PDV 18-29\%, liver 25\%; Huntington et al. 1985; Huntington \& Tyrrell, 1985; Reynolds $e t$ al. 1986). During the $21 \mathrm{~d}$ period, the relative contribution of PDV to WBO increased by $16 \%$ in ADLIB lambs and decreased by $21 \%$ in MAINT lambs (treatment, $P<0.05)$. Also, the relative contribution of liver to WBO increased $(32 \%)$ in ADLIB and decreased $(12 \%)$ in MAINT lambs (treatment $\times$ period, $P<0.01$ ).

The relations of MEI, body-weight and splanchnic blood flow to $\mathrm{O}_{2}$ consumption were analysed according to the model $Y=a W^{b}$, where $Y$ represents tissue blood flow or $\mathrm{O}_{2}$ consumption and $W$ represents MEI $(\mathrm{kJ} / \mathrm{d})$ or body-weight $(\mathrm{kg})$ (Tables 10 and 11$)$. The analyses were performed using linear regression of log-transformed values $(\log Y=\log$ $a+b \log W$ ). Hepatic $\mathrm{O}_{2}$ consumption changes more rapidly with changes in MEI than portal or splanchnic $\mathrm{O}_{2}$ consumption. No significant changes in the exponents were observed when any of the components were related to body-weight. 
Table 10. Regression coefficients for relations between metabolizable energy intake and splanchnic blood flow and oxygen consumption of sheep fed ad lib. or at maintenance levels*

(Values are means with their standard errors. Regression equation: $Y=a W^{b}$, where $W$ is metabolizable energy intake $(\mathrm{MJ} / \mathrm{d})$ )

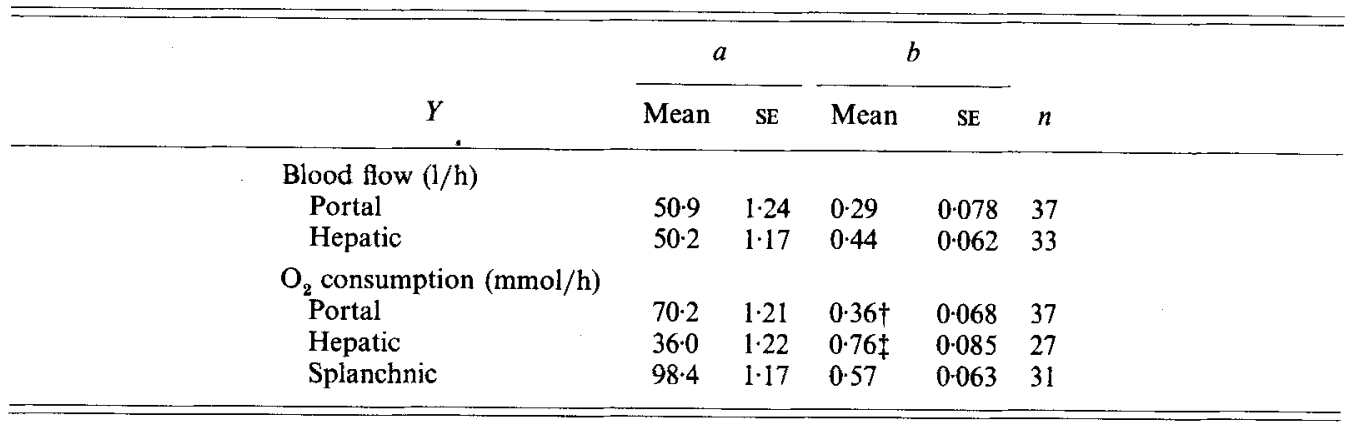

* For details, see p. 24 and Table 2.

$\dagger$ Mean value was significantly different from that of hepatic $\mathrm{O}_{2}$ consumption $(P<0.01)$.

$\ddagger$ Mean value was significantly different from that of splanchnic $\mathrm{O}_{2}$ consumption $(P<0 \cdot 01)$.

Table 11. Regression coefficients for relations between body-weight and splanchnic blood flow and oxygen consumption of sheep fed ad lib. or at maintenance levels*

(Values are means with their standard errors. Regression equation: $Y=a W^{b}$, where $W$ is body-weight $(\mathrm{kg}))$

\begin{tabular}{|c|c|c|c|c|c|}
\hline \multirow[b]{2}{*}{$Y$} & \multicolumn{2}{|c|}{$a$} & \multicolumn{2}{|c|}{$b$} & \multirow[b]{2}{*}{$n$} \\
\hline & Mean & SE & Mean & SE & \\
\hline \multicolumn{6}{|c|}{ Blood flow $(1 / h)$} \\
\hline Portal & $12 \cdot 2$ & 1.26 & $0.58 \dagger$ & $0 \cdot 215$ & 37 \\
\hline Hepatic & $8 \cdot 6$ & $1 \cdot 24$ & 0.76 & 0.207 & 33 \\
\hline \multicolumn{6}{|c|}{$\mathrm{O}_{2}$ consumption $(\mathrm{mmol} / \mathrm{h})$} \\
\hline Portal & $15 \cdot 1$ & $1 \cdot 25$ & 0.65 & $0 \cdot 207$ & 37 \\
\hline Hepatic & $2 \cdot 2$ & $1 \cdot 38$ & $1 \cdot 24$ & $0 \cdot 329$ & 27 \\
\hline Splanchnic & $8 \cdot 5$ & $1 \cdot 27$ & 0.03 & 0.232 & 31 \\
\hline
\end{tabular}

* For details, see p. 24 and Table 2.

$\uparrow$ No significant difference in any $b$ values.

\section{DISCUSSION}

An effect of level of nutrition or level of feed intake on the growth of visceral organs has been reported previously (Koong et al. 1982; Ferrell et al., 1986; Burrin et al. 1987). Results from the present study suggest that changes in visceral-organ growth in response to level of nutrition are associated with concurrent changes in blood flow and $\mathrm{O}_{2}$ consumption of visceral tissues. Several reports in sheep and cattle have indicated a positive relation between feed intake and portal blood flow (Bensadoun et al. 1962; Katz \& Bergman, 1969; Webster et al. 1975; Huntington \& Prior, 1983; Huntington, 1984). Although changes in portal blood flow tended to parallel those observed for feed intake, the exponent for the allometric equation (0.294) suggested that portal flow reacted sluggishly to changes in MEI. 
Others have reported a much higher correlation $(r 0.89-0.96)$ between portal blood flow and energy intake (Lomax \& Baird, 1983; Weighart et al. 1986) using linear-regression techniques. Changes in portal blood flow occur during all phases of nutrient assimilation in animals. Presentation and ingestion of food increase heart rate and cardiac output; these effects can be attenuated by adrenergic blockade, suggesting that sympathetic nerves are involved in modulated portal blood flow (Vatner et al. 1970). Other studies have indicated that mesenteric hyperaemia is localized in mucosal tissue and is limited to tissue actively involved in digestion (Chou et al. 1976; Dobson et al. 1981; Edelstone \& Holzman, 1981). In sheep, rumen infusion of acetate, propionate and butyrate increased rumen arterial blood flow by 10, 50 and $100 \%$ respectively (Sellers et al. 1964). Tissue metabolic activity has been implicated in local control of blood flow, which provides for steady delivery and removal of nutrients and end-products (Shepherd, 1982). In the present study, a reduction in $\mathrm{PDV} \mathrm{O}_{2}$ consumption in MAINT lambs appeared to be a function of reduced blood flow and changes in $\mathrm{A}-\mathrm{V} \mathrm{O}_{2}$ content.

The effects of level of intake on hepatic venous and arterial blood flow were much larger and more consistent than those observed for PDV. Previous reports have suggested that the feeding-induced increase in hepatic blood flow is a result of increased PDV blood flow, with no change in hepatic arterial flow (Katz \& Bergman, 1969; Edelstone \& Holzman, 1981). However, in progressively fasted dairy cows, a reduction in hepatic blood flow is a result of decreases in both portal blood flow and hepatic arterial flow (Lomax \& Baird, 1983). The divergence of hepatic blood flow observed in ADLIB and MAINT lambs was a result of changes in both portal and hepatic arterial blood flow. Changes in hepatic $\mathrm{O}_{2}$ consumption in response to feed intake were primarily a result of changes in blood flow rather than differences in $\mathrm{A}-\mathrm{V} \mathrm{O} \mathrm{O}_{2}$ content. The effects of feed intake on hepatic blood flow are presumably a result of increased liver metabolic activity; however, it has been suggested that control of hepatic blood flow is independent of metabolic activity (Lautt, 1980, 1983). Indeed, some hormones such as cholecystokinin, glucagon, pentagastrin and prostaglandins have vasodilatory effects on hepatic arterial vessels (Richardson \& Withrington, 1982).

Portal $\mathrm{O}_{2}$ extraction ratios were unaffected by level of intake; however, liver $\mathrm{O}_{2}$ extraction ratios tended to be greater in ADLIB than in MAINT lambs. An increase in $\mathrm{O}_{2}$ extraction by the liver may be a result of increased tissue metabolic activity or liver size. To assess liver metabolic activity per unit tissue, liver size was estimated using regression equations derived from serial-slaughter values collected in a previous study (D. G. Burrin, unpublished results): (ADLIB) $Y=10.5 \mathrm{~W}^{1 \cdot 15}$; (MAINT) $Y=21.6 \mathrm{~W}^{0.868}$, where $Y$ is liver size $(\mathrm{g})$ and $W$ is body-weight $(\mathrm{kg})$. Calculated estimates of tissue $\mathrm{O}_{2}$ consumption across treatments ranged from 0.21 to $0.39 \mathrm{mmol} / \mathrm{h}$ per $\mathrm{g}$ liver, which are considerably higher than reported rates of $\mathrm{O}_{2}$ consumption in vitro reported by Ferrell \& Koong (1985) and Burrin et al. (1987). Averaged across the $21 \mathrm{~d}$ period, mean rates of liver tissue $\mathrm{O}_{2}$ consumption per $g$ tissue were not changed in ADLIB and MAINT lambs, suggesting that level of feed intake did not affect tissue metabolic activity. This pattern is in agreement with previous observations based on in vitro $\mathrm{O}_{2}$ consumption (Burrin et al. 1987). Similar calculations suggest that hepatic blood flow per unit tissue was not affected by level of nutrition. Together these findings may suggest that liver blood flow is regulated to ensure a constant rate of delivery and removal of nutrients and end-products for a given amount of tissue and is, therefore, determined by liver mass.

The contribution of splanchnic tissue to WBO is significant and is subject to modulation by level of nutrition. In the control period, the PDV and liver accounted for roughly equal proportions of splanchnic $\mathrm{O}_{2}$ consumption, and together consumed $49-55 \%$ of WBO. The percentages of empty-body-weight represented by liver and gastrointestinal tract (GIT) are approximately 2 and 7 respectively. Thus, the rate of $\mathrm{O}_{2}$ consumption per unit weight is 
much higher in liver than in GIT. Studies in cattle have demonstrated that within the GIT, the proportion of $\mathrm{O}_{2}$ consumed by stomach and post-stomach tissues is similar (Huntington \& Reynolds, 1986). The changes in the relative contribution of splanchnic tissues to WBO in response to level of nutrition reflect changes observed in visceral organ size (Burrin et al. 1987) and are in agreement with similar studies in cattle (Reynolds \& Tyrrell, 1987).

In summary, level of nutrition influenced splanchnic blood flow and $\mathrm{O}_{2}$ consumption in young, growing lambs. These effects appeared to be more pronounced in liver than in PDV. The changes in splanchnic $\mathrm{O}_{2}$ consumption elicited by level of nutrition resulted in changes in the relative contribution of splanchnic tissues to WBO. These results further illustrate the importance of visceral organs in whole-animal energy metabolism.

The authors wish to acknowledge the assistance of Lynn Locker, Bruce Larsen, Cindy Felber, Debbie Robertson and Marc Bauer, Judy Huff in preparation, and Dr Rodger Johnson in statistics.

\section{REFERENCES}

Bell, A. W., Battaglia, F. C. \& Meschia, G. (1987) Relation between metabolic rate and body size in the ovine fetus. Journal of Nutrition 117, 1181-1186.

Bensadoun, A., Paladines, O. L. \& Reid, J. T. (1962). Effect of level of intake and physical form of the diet on plasma glucose concentration and volatile fatty acid absorption in ruminants. Journal of Dairy Science $\mathbf{4 5}$, 1203-1210.

Brody, S. (1945). Bioenergetics and Growth. New York: Reinhold Publishing Company.

Burrin, D. G., Bauer, M. L., Dubrovin, L. C., Britton, R. A. \& Ferrell, C. L. (1987). Nutrient restriction decreases visceral organ size and metabolic activity in sheep. Journal of Animal Science 65, Suppl. 1, 87 Abstr.

Chou, C. C., Hsieh, C. P., Yu, Y. M., Kvietys, P., Yu, L. C., Pittman, R. \& Dabney, J. M. (1976). Localization of mesenteric hyperemia during digestion in dogs. American Journal of Physiology 230, 583-589.

Dobson, A., Barnes, R. J. \& Comline, R. S. (1981). Changes in the sources of hepatic portal blood flow with feeding in the sheep. Physiologist 24, 15 Abstr.

Edelstone, D. I. \& Holzman, I. R. (1981). Gastrointestinal tract $\mathrm{O}_{2}$ uptake and regional blood flow during digestion in conscious newborn lambs. American Journal of Physiology 241, G289-G293.

Eisemann, J. H., Huntington, G. B. \& Ferrell, C. L. (1987). Blood flow to hindquarters of steers measured by transit time ultrasound and indicator dilution. Journal of Dairy Science 70, 1385-1390.

Ferrell, C. L. \& Jenkins, T. G. (1984). Energy utilization by mature, non-pregnant, non-lactating cows of different types. Journal of Animal Science 58, 234-243.

Ferrell, C. L. \& Koong, L. J. (1985). Response of body organs of lambs to differing nutritional treatments. In Energy Metabolism of Farm Animals, pp. 26-29 [P. W. Moe, H. F. Tyrrell and P. J. Reynolds, editors]. European Association of Animal Production, Publication no. 32. Totowa, New Jersey: Rowman and Littlefield.

Ferrell, C. L., Koong, L. J. \& Nienaber, J. A. (1986). Effect of previous nutrition on body composition and maintenance energy costs of growing lambs. British Journal of Nutrition 56, 595-605.

Graham, N. McC., Searle, T. W. \& Griffiths, D. A. (1974). Basal metabolic rate in lambs and young sheep. Australian Journal of Agricultural Research 25, 957-971

Holliday, M. A., Potter, D., Jarrah, A. \& Bearg, S. (1967). The relation of metabolic rate to body-weight and organ size. Pediatrician Research 1, 185-195.

Huntington, G. B. (1984). Relationship of portal blood flow to metabolizable energy intake of cattle. Canadian Journal of Animal Science 64, Suppl. 1, 16-17.

Huntington, G. B. \& Prior, R. L. (1983). Digestion and absorption of nutrients by beef heifers fed a high concentrate diet. Journal of Nutrition 113, 2280-2288.

Huntington, G. B., Prior, R. L. \& Britton, R. A. (1980). Glucose and lactate absorption and metabolic interrelationships in lambs switched from low to high concentrate diets. Journal of Nutrition 110, 1904-1910.

Huntington, G. B. \& Reynolds, C. K. (1986). Blood flow and nutrient flux across stomach and post-stomach tissues in beef steers. Federation Proceedings 45, 606.

Huntington, G. B. \& Tyrrell, H. F. (1985). Oxygen consumption by portal-drained viscera of cattle: comparison of analytical methods and relationship to whole-body oxygen consumption. Journal of Dairy Science 68, $2727-2731$.

Huntington, G. B., Varga, G. A., Reynolds, P. J. \& Tyrrell, H. F. (1985). Net absorption of nutrients and oxygen consumption by portal-drained viscera in relation to energy metabolism by Holstein cattle. In Energy Metabolism of Farm Animals, pp. 22-25 [P. W. Moe, H. F. Tyrrell and P. J. Reynolds, editors]. European Association of Animal Production, no. 32. Totowa, New Jersey: Rowman and Littlefield. 
Jenkins, T. G. \& Ferrell, C. L. (1983). Nutrient requirements to maintain weight of mature, non-lactating, nonpregnant cows of four diverse breed types. Journal of Animal Science 56, 761-770.

Katz, M. L. \& Bergman, E. N. (1969). Simultaneous measurements of hepatic and portal venous blood flow in the sheep and dog. American Journal of Physiology 216, 946-952.

Kleiber, M. (1947). Body size and metabolic rate. Physiological Reviews 27, 511-541.

Koong, L. J., Nienaber, J. A., Pekas, J. C. \& Yen, J. T. (1982). Effects of plane of nutrition on organ size and fasting heat production in pigs. Journal of Nutrition 112, 1638-1642.

Lautt, W. W. (1980). Control of hepatic arterial blood flow: independence from liver metabolic activity. American Journal of Physiology 239, H559-H564.

Lautt, W. W. (1983). Relationship between hepatic blood flow and overall metabolism: the hepatic arterial buffer response. Federation Proceedings 42, 1662-1666.

Ledger, H. P. \& Sayers, A. R. (1977). The utilization of dietary energy by steers during periods of restricted food intake and subsequent realimentation. I. The effect of time on maintenance requirements of steers held at constant live weights. Journal of Agricultural Science 88, 11-26.

Lomax, M. A. \& Baird, G. D. (1983). Blood flow and nutrient exchange across the liver and gut of the dairy cow. British Journal of Nutrition 49, 481-496.

Marston, H. R. (1948). Energy transactions in sheep. I. The basal heat production and the heat increment. Australian Journal of Science Research B1, 91-129.

Munro, H. N. (1969). The evolution of protein metabolism in mammals. In Mammalian Protein Metabolism, vol. 3, pp. 151-171 [H. N. Munro, editor]. New York: Academic Press.

National Research Council (1984). Nutrient Requirements of Beef Cattle. Washington, DC: National Academy of Sciences.

Nienaber, J. A. \& Maddy, A. C. (1985). Temperature-controlled multiple-chamber indirect-calorimetry. Design and operation. Transactions of the AS AE 28, 555-562.

Reynolds, C. K., Huntington, G. B., Tyrrell, H. F. \& Reynolds, P. J. (1986). Splanchnic tissue and whole animal oxygen consumption by lactating Holstein cows. Journal of Dairy Science 69, Suppl. 1, 193.

Reynolds, C. K. \& Tyrrell, H. F. (1987). Effect of diet intake on net visceral tissue metabolism in growing beef heifers. Journal of Animal Science 65, Suppl. 1, 477.

Richardson, P. D. I. \& Withrington, P. G. (1982). Physiological regulation of the hepatic circulation. Annual Review of Physiology 44, 57-69.

SAS (1982). SAS User's Guide: Statistics. Cary, NC: Statistical Analysis System Institute Inc.

Schaefer, A. L. \& Krishnamurti, C. R. (1984). Whole body and tissue fractional protein synthesis in the ovine fetus in utero. British Journal of Nutrition 52, 359-369.

Sellers, A. F., Stevens, C. E., Dobson, A. \& McLeod, F. D. (1964), Arterial blood flow to the ruminant stomach. American Journal of Physiology 207, 371-377.

Shepherd, A. P. (1982). Local control of intestinal oxygenation and blood flow. Annual Review of Physiology 44, 13-27.

Smith, N. E. \& Baldwin, R. L. (1974). Effects of breed, pregnancy and lactation on weight of organs and tissues in dairy cattle. Journal of Dairy Science 57, 1055-1060.

Steel, R. G. D. \& Torrie, J. H. (1980). Principles and Procedures of Statistics. New York: McGraw-Hill Book Co.

Ushioda, E., Nuwayhid, B., Tabsh, K., Erkkola, R., Brinkman, R. III \& Assali, N. S. (1982). Mixing problems in using indicators for measuring regional blood flow. American Journal of Obstetrics and Gynecology 142, $74-86$.

Vatner, S. F., Franklin, D. \& Van Cilters, R. L. (1970). Mesenteric vasoactivity associated with eating and digestion in the conscious dog. American Journal of Physiology 219, 170-174.

Webster, A. J. F. (1981). The energetic efficiency of metabolism. Proceedings of the Nutrition Society 40, 121-128.

Webster, A. J. F., Osuji, P. O., White, F. \& Ingram, J. F. (1975). The inftuence of food intake on portal blood flow and heat production in the digestive tract of sheep. British Journal of Nutrition 34, 125-139.

Wieghart, M., Slepetis, R., Elliot, J. M. \& Smith, D. F. (1986). Glucose absorption and hepatic gluconeogenesis in dairy cows fed diets varying in forage content. Journal of Nutrition 116, 839-850. 